\title{
THE VALUE CONTRIBUTION OF SUSTAINABILITY REPORTING - AN EMPIRICAL EVIDENCE FOR REAL ESTATE COMPANIES
}

\author{
Nelufer Ansari ${ }^{1}$, Marcelo Cajias ${ }^{2}$, Sven Bienert $^{1}$ \\ ${ }^{1}$ University of Regensburg, IRE|BS Department of Real Estate, Competence Center of \\ Sustainable Real Estate \\ ${ }^{2}$ PATRIZIA Immobilien AG and Germany and University of Regensburg
}

\begin{abstract}
Sustainability has evolved into one of the major challenges for society as a whole and for the business world. This changing perception over the past two decades has resulted in increased requirements for corporate sustainability. In order to meet stakeholders' desire for information, documenting the corporate contribution to sustainability becomes an important aspect of companies' stakeholder communication. Especially the real estate industry bears a high level of responsibility, since this sector is regarded as one of the major triggers of anthropogenic climate change and resource exploitation, making sustainable corporate management and the communication thereof quite essential. As the leading authority in sustainability reporting, the Global Reporting Initiative (GRI), published an internationally recognized common framework, in order to ensure the comparability and standardization of corporate sustainability reporting. This paper analyses, for the first time, whether sustainability reporting has an influence on the stock prices of real estate companies. Using the methodology of event study, research with a global sample (Europe, USA and Australia) shows a clear positive impact. Thus, sustainability and its communication do indeed have an impact on corporate valuation, so that efforts to promote corporate sustainability cannot be branded simply as altruism. In fact, sustainability is of decision-making relevance for shareholders and investors and therefore constitutes a success factor for companies. The results of this study provide empirical evidence based on data from listed real estate companies.
\end{abstract}

Keywords: Global Reporting Initiative, Sustainability Reporting, Corporate Social Responsibility, corporate performance, event study, Listed Real Estate Companies

Suggested Citation: Ansari, N./ Cajias, M./ Bienert, S. 2015. The Value Contribution of Sustainability Reporting - An Empirical Evidence for Real Estate Companies. ACRN Oxford Journal of Finance and Risk Perspectives, 4(4). October 2015, from http://www.acrn-journals.eu/jofrp/jofrp0404.html, p. 190-205. 


\section{Introduction}

Threats of the anthropogenic climate change, the still all too prevalent poverty in large parts of the world, the exploitation of natural resources, turmoil in the business world, such as spectacular failures in the economic system, have all triggered a process of rethinking at the level of society as well as of corporations. The behavior of corporates, as one of the main contributors to this development, have moved into the center of attention and critical voices have been calling for greater restraints of firms' aspirations for profit maximization. A business-as-usual approach is no longer acceptable. This is especially so, given that, despite worldwide efforts to reduce anthropogenic climate change, global greenhouse gas emissions in $\mathrm{CO}_{2}$-equivalents increased in the period $2012-2013$ by a further $3 \%$ p.a. and now amount to around 32 gigatonnes p.a., the highest ever measured value (Munich Re, 2013).

It is therefore not surprising that over the past two decades, sustainable development has become one of the major challenges of globally operating companies (Melé, Debeljuh, \& Arruda, 2006; Skouloudis, Evangelinos, \& Kourmousis, 2009). Thus, corporate responsibility is forcing companies to anticipate social and environmental effects in their decision-making processes and to integrate CSR into corporate strategies (Cajias \& Bienert, 2011). Hence, in accordance with the triple bottom line, companies now have to balance social, environmental and economic objectives, in order to meet the needs of internal and external stakeholders. However, the success of these efforts stands or falls with appropriate communication. In this context, (particularly) sustainability reports such as the frameworks of the Global Reporting Initiative - as the worldwide sustainability reporting standard - enjoy increasing popularity.

Especially the construction and real estate industry, as one of the key drivers of resource scarcity and climate change, bears great responsibility in promoting sustainable development. According to the OECD, the construction, operation and dismantling of buildings, as well as construction works, are together responsible for ca. 25-40\% of global energy consumption, for approximately $30 \%$ of raw material consumption, for $30-40 \%$ of greenhouse gas emissions, for $30-40 \%$ of waste volume and for $20 \%$ of global water consumption (Nelson, Rakau, \& Doerrenberg, 2010). The United Nations even assume that considering the population growth associated with massive construction activities, the greenhouse gas emissions caused by the real estate sector could even double in the next two decades (UNEP, 2009). For the European Union, Nelson et al. (2010) estimate that the construction and real estate sector is responsible for $42 \%$ of final energy consumption and for about $35 \%$ of the total greenhouse gas emissions. These results show clearly that an awareness of sustainability and a pro-active approach towards sustainable development is crucial for this industry and for the entire system in terms of intergenerational justice.

However, promoting this desired "sustainable or responsible behavior" remains a major issue among practitioners and researchers. If sustainability were only a matter of altruism, corporations would always opt for profit maximization. Thus, a large body of literature is dedicated to analyzing the impact of corporate sustainability on corporate success, rejecting the hypothesis of pure altruism among CSR-focused firms. In this context, the aim of this paper is to analyze, by means of an event study, the impact of sustainability reporting on listed real estate companies. By doing so, we wish to find out, whether investors reward sustainability reports with higher returns and provide evidence of a positive impact of sustainable behavior and the stock returns for real estate companies. The paper is divided into five subsections. A literature review that provides more information on sustainability and considers previous work on reporting, is followed by a description of the research approach, the sample and research design, as well as a description of the methodology of event study. The results comprise statistical significance tests and are followed by some conclusions. 


\section{Literature Review}

\section{Corporate Social Responsibility (CSR)}

The term Corporate Social Responsibility (CSR) or Corporate Sustainability has evolved into a major concept for corporate contribution to sustainable development. It is undeniable that CSR has developed in importance and significance, from an irrelevant and rather fashionable topic to one of the most widely used concepts in the business world (Lee, 2008). Both concepts are interlinked and widely used, although there is still no globally accepted definition. The most common definition is the one presented by the European Commission, according to which CSR is "a concept whereby companies integrate social and environmental concerns in their business operations and in their interaction with their stakeholders on a voluntary basis" (COM 2001, 366). It further states that "Corporate social responsibility concerns actions by companies over and above their legal obligations towards society and the environment" in order to increase competitiveness (COM 2011, 0681). Hence, CSR reveals all the environmental, social and economic aspects of a company that has either a direct or indirect impact on business (Turcsanyi \& Sisaye, 2013) and its stakeholder groups such as employees, investors, communities and especially in the case of multinational corporations, the broader society and environment.

The basis for corporate sustainability remains the convening of the World Commission on Environment and Development (also commonly known as the Brundtland Commission) by the United Nations General Assembly in 1983. The main aim of this initiative was to unite countries in pursuing sustainable development together. The 1987 report "Our Common Future" characterized sustainable development as one that meets the needs of present generations without compromising the ability of future generations to meet their own needs (Brundtland Report, 1987). Agenda 21 - a comprehensive action plan to promote sustainable development - entailed the Agreement of 178 countries at the Earth Summit UN Conference on the Environment and Development in Rio de Janeiro in 1992.

\section{The reporting framework on sustainability}

Ever since, corporate reporting has been an ideal medium for stakeholder communication. Traditionally, financial reporting was predominantly important to shareholders and potential investors. However, with the increased awareness of sustainability and sustainable investments among investors, shareholders, as well as society as a whole, critics of corporate reporting practices have become manifold. The failure of annual reports or other regulatory files such as $10 \mathrm{Ks}$ to provide detailed information on corporate environmental and social performance, has been at the center of demands to report such issues more meaningfully. The solution seemed to be reporting that covers the triple-bottom-line with its economic, social and environmental dimensions. Despite the number of companies publishing sustainability reports growing at a rapid pace, the presented information continues to lack uniformity, consistency and comparability, giving rise to calls for a global standard in sustainability reporting (Dilling, 2009). Especially because corporate reporting on sustainability is still a matter of voluntary commitment, the major challenge is to overcome "greenwashing" and (subjective) interpretational tendencies (Laufer, 2003; Ramus \& Montiel, 2005).

The Global Reporting Initiative (GRI), as one of the most valued non-profit organizations, attempted to fill this void by providing a comprehensive sustainability framework. Established in 1997, out of the coalition between Environmentally Responsible Economies (CERES) and the United Nations Environment Program (UNEP), the GRI is a multi- 
stakeholder non-profit institution located in the Netherlands, with the main aim of providing globally accepted standards for sustainability reporting. Hence, its mission is "to enhance responsible decision making by promoting international harmonization in reporting relevant and credible economic, environmental and social performance information" (GRI, 2002). Based on a broad understanding of the triple-bottom-line, the GRI developed and published its first Exposure Draft of GRI Sustainability Reporting Guidelines in 1999. This was followed by the launch of the GRI G3 - the third generation sustainability reporting framework and the publication of the G3.1 guidelines - an update and completion of G3, with expanded guidance on reporting gender, community and human rights-related performance. In May 2013, GRI released the fourth generation of its guidelines - GRI G4. Sector supplements provide guidance for diverse industries such as the real estate industry.

\section{Determinants for sustainability disclosure}

Though sustainability reports are not mandatory, they fulfill an accountability function towards stakeholders. By providing information, they reduce information asymmetries between the company and its stakeholders. Thus, information beyond what is available in the financial disclosure has evolved into an essential means of maintaining a relationship of trust with stakeholders and as such, a "license to operate" (Krajnc \& Glavi, 2005; Gilbert \& Rasche, 2007; Alonso-Almeida, 2009). Beside this, there are impacts on different levels of the corporation. The effect on employees is twofold. On the one hand, by reporting on corporate activities regarding sustainability, the employees are informed and gain a better understanding of the reasons for specific actions. On the other hand, the firm's sustainable behavior also motivates employees and can increase the attractiveness of the company for potential employees (COM, 2001; Weber, 2008). CSR affects employees with regard to work-life balance, remuneration, working conditions etc. As such, CSR and reporting it can help to increase the overall level of employee information about sustainability, thus raising satisfaction and work ethics. Furthermore, by reporting on corporate responsibility, corporations can attract socially responsible investors. The Socially Responsible Investment (SRI) market has reached huge volumes in the past few years. According to Eurosif European SRI (2014), the market for socially responsible investments in Europe has grown from 13.8 billion to 16.8 billion, a total growth of $22 \%$. Studies by Geczy, Stambaugh, \& Levin (2003) and Bauer, Koedijk, \& Otten (2005) reveal that more and more capital is invested in ethical investment funds, demonstrating the increasing demand for ethical investments opportunities by investors.

Another stream of literature assumes that on the corporate side, sustainability disclosure is a media tool that "reveals the positive and negative aspects of a firm's strategies" (Cajias \& Bienert, 2011). However, there are contradictionary opinions. While the study of 600 European companies by Albers and Gunther (2010) showed that highly capitalized companies and those adhering to sustainability indices are more likely to publish social reports, Cajias, Geiger, and Bienert (2012) demonstrated that increased media presence goes along with an increased probability of greater sustainability disclosure. Cajias and Bienert (2011) also focus on whether financial transparency determines CSR, since according to them, media visibility correlates highly with company size. The analysis of listed real estate companies showed furthermore that business complexity and financial transparency enhance the provision of sustainability information across Europe. For Germany Gamerschlag, Möller \& Verbeeten (2011) undertake an analysis of the CSR disclosure of 130 listed companies to investigate the determinants of sustainability reports. The results show that disclosure of german companies is determined among others by their shareholder structure and visibility. In particular, higher environmental disclosure triggers higher financial performance. 


\section{Sustainability disclosure and corporate performance}

Sustainability reporting and financial performance have not been subject to many studies, especially in the real estate industry. Murray, Sinclair, Power, and Gray (2006) analyzed the 100 largest UK companies (across all sectors) and found out that there is no relationship between market returns and corporate social and environmental disclosure. However, the longitudinal analysis proved a significant relationship between positive returns and high levels of disclosure, meaning that companies with high abnormal returns are also likely to have greater sustainability disclosure, due to the greater amount of resources that can be diverted to various sustainability areas. Jones, Frost, Loftus, \& van der Laan (2007) analyzed the value relevance of sustainability reporting by means of a sustainability index regressed against a wide range of financial and market performance metrics of 100 listed Australian companies. The results show a strong relationship between sustainability disclosure and a range of corporate financial performance metrics, such as operating cash flow to total assets, working capital to total assets, and capital expenditure to assets. Especially for the real estate sector there are, to the best of our knowledge, no studies analyzing the value contribution of sustainability reports. Hence, this research helps fill the void and makes a contribution to the academic research in this specific field.

\section{Research approach}

Abnormal returns on the stock market reflect current performance and investor expectations about the future profitability and growth of a company. These abnormal returns can be triggered by "events" which can refer to the announcement of new information or occurrences that are not already priced by stock prices. We focus on testing whether the publication of sustainability reports results in abnormal returns on the stock market, so that they have a positive impact on stock values and consequently on companies' long-term growth. The positive valuation of the company in terms of abnormal returns might be the result of detailed and explicit information on sustainability, which is provided in the (GRI-) report, as it is directly connected with a more specific management and long-term corporate strategy. The submission and acceptance of a sustainability report is only successful if the company can prove the integration of sustainability into corporate strategy. This can be achieved by the submission of the first sustainability report. Thus, the submission of the following reports to the GRI provides information on changes in the sustainability key performance indicators. Hence, shareholders and potential investors link sustainable corporate management concerning all sustainability dimensions - economic, ecological and social with lower risk and higher corporate legitimacy, thus also having a positive effect on longterm corporate performance.

Given the broad findings of previous literature, if sustainability disclosures are considered value-relevant to investors, we would expect higher (lower) sustainability disclosing entities to have relatively higher (lower) abnormal stock returns. Hence, the specific research question is whether sustainability reports affect stock prices positively and therefore do pay off. Especially, if one considers the cost of preparing sustainability reports and of measuring sustainability performance etc., positive results would indicate that the information on sustainability as provided in the reports, is of decision-making relevance for investors and capital markets.

This paper is, to the best of our knowledge, one of the first to use the GRI-database for empirical studies on abnormal stock returns. Hence, a disclosure in conformity with GRI 
might be accepted and appreciated more widely in the market than other voluntary disclosure forms, and also enables greater visibility in capital markets. Thus, the GRI publication is experiencing a greater acceptance among shareholders and investors, and hence seems of greater use in decision-making, in relation to traditional disclosure in annual company reports. If really so, this would imply a greater trustworthiness of GRI, compared to company publications, since GRI publishes the reports after an internal verification process.

\section{Sample description and research design}

The data used to determine the listed real estate companies disclosing sustainability reports was derived from the GRI database. We aggregated and screened the GRI reporting data room for real estate and construction companies. Thus, the initial sample covered 385 construction and real estate companies worldwide, that published sustainability reports during the from 1999 till 2014. Subsequently, this data set was matched with the real estate data room of Thomson Reuters DataStream. For the matching procedure, it was necessary to gather the company-specific ISIN information, since the GRI list only contains the company names. Hence, the ISIN was researched for each company by means of DataStream and internet research. As a result, the initial GRI long list was reduced by all non-listed companies, insolvent and non-operating companies, as well as companies with no applicable information, resulting in a remaining data space of 190 listed real estate companies. For these companies, extensive internet research, taking into account especially the corporate and GRI website, was undertaken to find the exact publication dates of their sustainability reports. However, the publication date was not available for all researched companies, leading to a reduced list of 94 companies. A further adjustment, eliminating all obsolete data such as companies with no information on performance measures, real estate funds, etc. yielded a final sample of 89 publicly listed real estate companies.

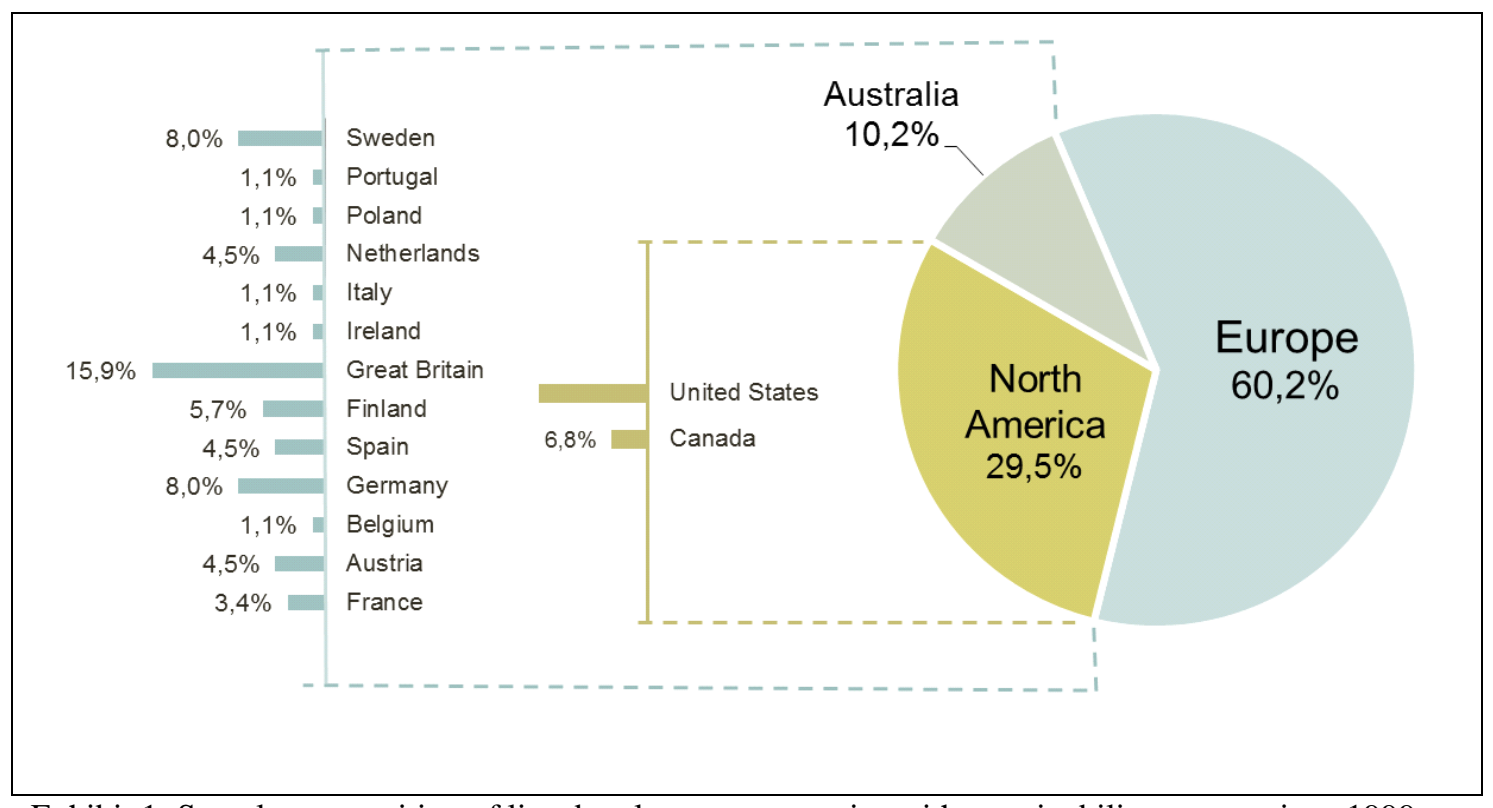

Exhibit 1: Sample composition of listed real estate companies with sustainability reports since 1999

The pie chart illustrates the final sample structure.

The data covers three continents: Europe with the largest share of $60.2 \%$, followed by North America with a share of $29.5 \%$ and Australia with the smallest share of $10.2 \%$. For European companies, the UK exhibits the highest share of about $15.9 \%$, followed by 
Germany and Sweden with $8.0 \%$ each. The North American sample consists of the United States with $22.7 \%$ and Canada at around $6.8 \%$. For this final short list we started a double approach: Firstly, we used the publication data on the GRI website and secondly, the publication data on the companies' homepages, i.e. the press release. For the time period 1999 to 2014, we identified 227 (71.2\%) GRI publication observations and 92 (28.8\%) corporate press releases. Hence, the total sample covered 89 companies with 319 observations of sustainability report publications.

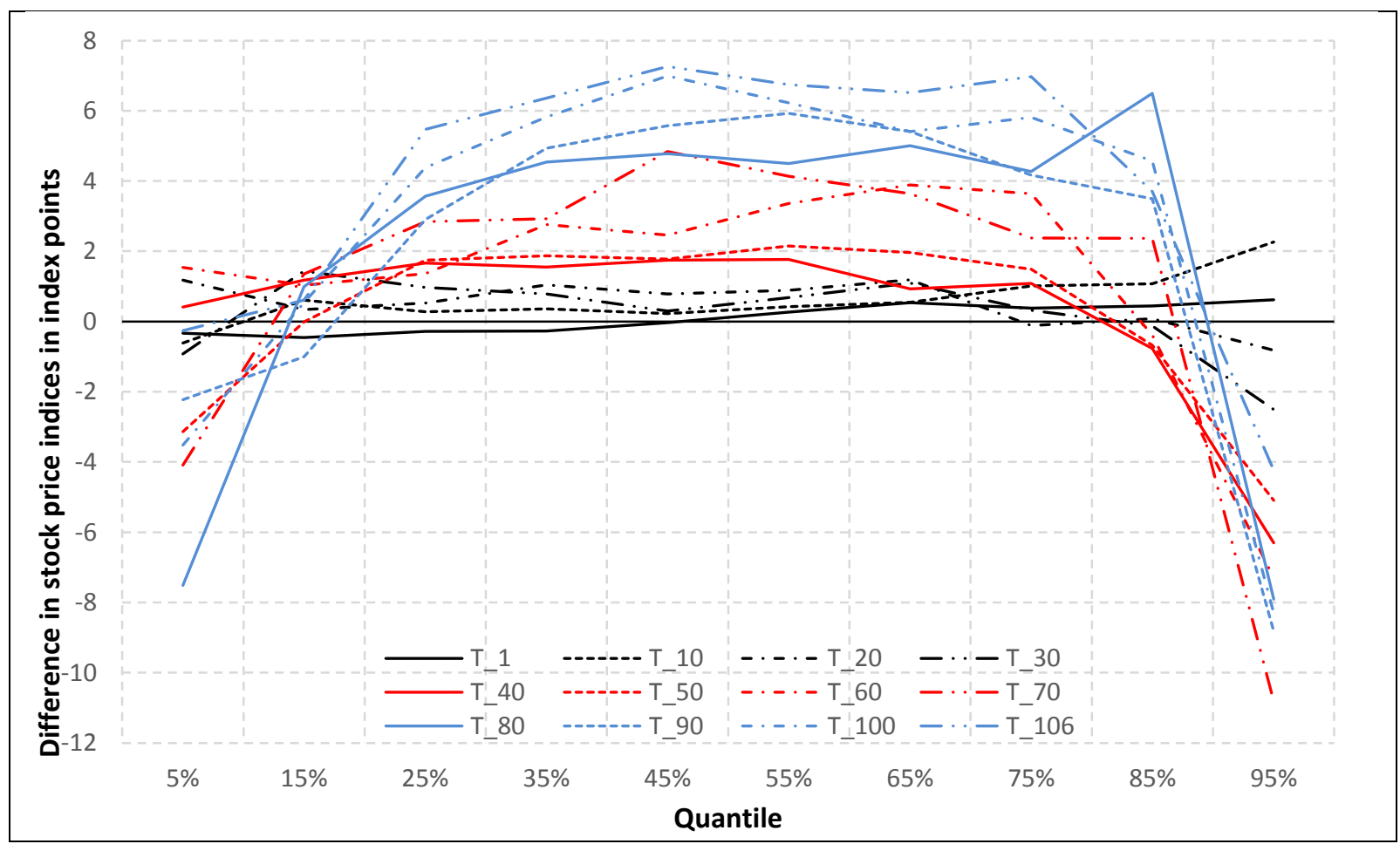

Exhibit 2: Distribution of the impact of sustainability report releases on companies' stock price indexes

For this analysis, the total return index of each observed real estate company was set to 100 on the event day the release of their sustainability report. We then calculated the difference in the stock price index after and before the event for each of the 89 real estate companies. Since our investigation window is 106 days, we report only 12 periods. The plot shows the distribution of differences across several quantiles for each of the chosen windows, starting with 1 day and ending in 106 days. A positive difference in a specific quantile indicates that the total return index was higher after the report-release, compared to the same period of time before the report release.

The graph shows the distribution of the differences (after and then minus before the sustainability report release) of the total return index for each observation on the first day after release, in ten days steps and on the last six days of the examination window. This first simple descriptive analysis shows that the release of sustainability reports has a substantial impact on the total return index across the sample. The analysis shows that for about $70 \%$ of the observations, the difference in the total return index for after-report release, compared to before-report release, was positive. The positive effect on returns becomes more evident that is stronger the further you go from the event date. Thus, after 106 days, almost $70 \%$ of the observations had a return index value between $+0,6$ and $+3,7$ on average. Ten days after the report release, $90 \%$ of all observations show a positive value for the "after-minus-before" total return index. This result is also some initial evidence of the market efficiency hypothesis, because new information - the release of sustainability report - is incorporated into the share 
prices shortly (2 days) after the event date (McWilliams \& Siegel, 1997; Lloyd Davies \& Canes, 1978).

\section{Research Methodology}

Fama (1970) decisively influenced research on the impact of new, publicly available information on stock prices. Ever since, event studies have been an integral part of economic research, as the main goal is to determine the effect of new information on the market value of a company. From this, it is possible to derive whether or not the information is useful to shareholders for decision making. Event studies are conducted under the premise that the considered capital market processes publicly available information quickly and (almost) completely. This premise is based on the hypothesis of efficient capital markets formulated by Fama (1970, p. 383): "The primary role of the capital market is [the] allocation of ownership of the economy's capital stock. In general terms, the ideal is a market in which prices provide accurate signals for resource allocation: that is, a market in which firms can make production-investment decisions, and investors can choose among the securities that represent ownership of firms' activities under the assumption that security prices at any time fully reflect all available information. A market in which prices always fully reflect available information is called efficient." This semi-strict informational efficiency prevails in the market if all publicly available information is reflected immediately and completely in the current market price. Overall, many studies indicate that there is a latent semi-strict information efficiency in all major capital markets (Spreemann, 2006), which is the basic assumption in event studies. Thus, the influence of a piece of information on corporate value can be read from the share-price reaction upon information notice. Since discounted cash-flow methods are dependent on internal data as well as company individual risk perception, event studies provide a wide and more objective mean for the estimation of capital market reactions (McWilliams \& Siegel, 1997).

The first event studies - whose methodology remains basically valid - were undertaken by Ball and Brown (1968) and Fama (1970), and essentially evaluate the impact of profit reports and stock splits on capital markets. More precisely, they analyze the influence of profit reports on the excess returns calculated according to the market model. The underlying rationale is that if abnormal returns were observable, they presumably incorporate the information that is relevant for an individual company. The present study's application of the event study method is undertaken in accordance with the procedure introduced by MacKinley (1997). Generally, the method can be divided into the following steps:

- identification of the event and event window

- modeling and estimating the share price reaction

- summing up and interpretation of the abnormal returns

\section{Identification of event and event window}

We define the event as the date of publication of sustainability reports. However, we do not differentiate between reports compiled according to GRI G3 or G4 framework, or sustainability reports compiled according to company's own framework. However, we do consider two different release dates: firstly, the date when the report is published in the GRI database - hence accepted by the GRI - and secondly, the release date by the company via the firm's internal press release. The most crucial research design aspect in event methodology 
probably concerns the length of event window. The main reason is the increasing probability of overlapping or parallel events, resulting in biased results. Therefore, we decided on an event window of 106 days before and 106 days after the event in daily steps covering a total period of 91 trading days. This event window length seems ideal for this research and is in accordance with McWilliams \& Siegel (1997), as they analyzed different event studies on sustainability, finding that the event periods chosen ranged symmetrically up to 181 trading days. However, the smaller the event window, the lower the risk of confounding events and thus the more accurate the results (Gebken, 2008; Peterson, 1987).

\section{Modeling and estimating share price reaction}

In order to assess the impact of a GRI report release on the stock price it is necessary to measure the (cumulative) abnormal returns. Conceptually, the event analysis differentiates between returns that would have been expected in the absence of the analyzed event (normal or expected returns) and returns that are caused by the respective event (abnormal returns). Hence, the abnormal return over the event period corresponds to the actually observed return of a security in the capital market, less the estimated return of the security over the event period. For firm $i$ at the event date $t$, the abnormal return can be described as

$$
A R_{i, t}=R_{i, t}-\hat{R}_{i, t}
$$

, where $A R_{i, t}, R_{i, t}$ and $\hat{R}_{i, t}$ are the abnormal, actual and normal (estimated) returns respectively. Though this might seem trivial, among researchers, it is common knowledge that the research outcomes depend on the proper estimation of the normal (expected) return. The large body of models can generally be grouped into two categories of model: statistical and economic models. While models in the first category rely mainly on statistical assumptions, models in the second category take into account addition assumptions regarding investor behavior, for a more precise estimation of the normal returns. However, research has proven that the additional factors are not associated with higher explanatory power, resulting in such economic models almost no longer being used (MacKinley, 1997). Thus, the most important statistical methods within the event study methodology are the simple constant-mean model and the prevalent market model, which differ mainly in the underlying assumption on the behavior of asset returns. The constant mean model is based on the assumption that the best predictor of a company's normal return is the company's average security return prior to the event window. According to this model, the normal period- $t$ return of a security $i$ can be described as

$$
\widehat{A R}_{i, t}=R_{i, t}-\overline{\hat{R}}_{i, t}=\frac{1}{T} \sum_{t=1}^{T} R_{i, t}+\varepsilon_{i, t}
$$

Hence, the normal expected return $\bar{R}_{i, t}$ of security $i$ is equal to the average return, meaning it is constant during the estimation period, as well as during the event window. $\varepsilon_{i, t}$ is a noise term for security $i$, with an expected mean $\mu\left(\varepsilon_{i, t}\right)=0$ and variance $\operatorname{var}\left(\varepsilon_{i, t}\right)=\sigma_{\varepsilon_{i, t}}^{2}$. Despite its simplicity, the constant-mean model is expected to generate results that are quite similar to those of more complex models (Brown \& Warner, 1985; Brown \& Weinstein, 1980).

One of the most prevalent approaches in event study methodology is the market model, since evidence has suggested that the model will perform in most circumstances, as well as, if not better than any other alternative (Armitage, 1995). Generally, for statistical models, it is 
required that asset returns be jointly multivariate normal, independent and identically distributed over time, as explained by Campbell, Lo, \& MacKinley (1997). Consequently, the normal return for any given security $i$ is according to the market model, defined as

$$
\hat{R}_{i, t}=\hat{\alpha}_{i}+\hat{\beta}_{i} R_{m, t}+\varepsilon_{i, t}
$$

, whereby $\hat{R}_{i, t}$ and $R_{m, t}$ are the estimated normal period- $t$ returns of the asset $i$ and the market return $m$ respectively. $\varepsilon_{i, t}$ is the error noise term with $\mu\left(\varepsilon_{i, t}\right)=0$ and $\operatorname{var}\left(\varepsilon_{i, t}\right)=\sigma_{\varepsilon_{i, t}}^{2}$. The basic idea of the model is the division of the normal return into two components, into a particular market-driven return component and a security-specific component, meaning a firm-specific dependant return. Hence, the market model incorporates the security's sensitivity to market movements into the prediction of the normal return and relates the return of any given asset to the return from the market portfolio (MacKinley, 1997). This asset-specific sensitivity to market movements is measured by the estimated regression via OLS over an estimation window of 91 trading days. In order to determine the market return, a benchmark is required. Brown and Warner (1980) indicate that the choice of benchmark has a significant effect on the results of the event study. For the determination of the market return, we use the main broad market indices of the respective country such as DAX, CAC, S\&P, FTSE, etc. The abnormal returns $\widehat{A R}_{i, t}$ for a security $i$ at time $t$ are calculated as follows:

$$
\widehat{A R}_{i, t}=R_{i, t}-\hat{R}_{i, t}=R_{i, t}-\hat{\alpha}_{i}-\hat{\beta}_{i} R_{m, t}
$$

\section{Aggregation and testing statistics for the significance of abnormal returns}

After calculating the abnormal returns $\widehat{A R}_{i, t}$ for all $i$ securities over the event window $t$, it is necessary to aggregate these abnormal returns, in order to test for their significance and whether inferences can be drawn. Through the concept of cumulative returns, multi-period event windows can be accommodated and therefore, in order to test for significant abnormal returns, the $[i \times t]$ matrix containing the $\widehat{A R}_{i, t}$ can be aggregated, firstly over time across the event window $t$, cross-sectionally across each company $i$ or lastly across both company $i$ and time $i$ (Fama, 1970). The Cumulative Abnormal Return $(\widehat{C A R})$ aggregates the abnormal returns for each company over time. This is within the event window beginning in $T_{1}$ and ending in $T_{2}$ as follows:

$$
\widehat{C A R}_{i}\left(T_{1}, T_{2}\right)=\sum_{t=T_{1}}^{T_{2}} \widehat{A R}_{i, t}
$$

with

$$
\operatorname{var}\left(\overline{\overline{C A R}}\left(T_{1}, T_{2}\right)\right)=\sum_{t=T_{1}}^{T_{2}} \operatorname{var}\left(\overline{\widehat{A R}}_{t}\right)
$$

In other words, the cumulative abnormal return is the sum of all abnormal returns during the event window. The calculation of $\operatorname{var}\left(\overline{\overline{C A R}}\left(T_{1}, T_{2}\right)\right)$ eliminates overlapping events and sustains the assumption of uncorrelated abnormal returns between the distinctive observations. The mean abnormal returns of all companies at each point of time over the event window are calculated as:

$$
\overline{\widehat{A R}}_{t}=\frac{1}{N} \sum_{i=1}^{N} \widehat{A R}_{i, t}
$$


with

$$
\operatorname{var}\left(\widehat{\widehat{A R}}_{t}\right)=\frac{1}{N^{2}} \sum_{i=1}^{N} \sigma_{\varepsilon_{i}}^{2}
$$

Hence, the cumulative average abnormal return $\overline{\widehat{A R}}_{t}$ is calculated as the sum of all securities' abnormal returns divided by the number of observed securities. This is similar to an equal weightening of $\mathrm{N}$ securities. Hence, after each period $\mathrm{t}$, the securities are redistributed, meaning that those with a higher return are sold in the following period to buy securities with a relatively low return. The aggregation of the cumulative abnormal returns over time and securities, that is, the impact of the event over the event window, is calculated as followings:

$$
\left(\overline{\overline{C A R}}\left(T_{1}, T_{2}\right)\right)=\frac{1}{N} \sum_{i=1}^{N} \overline{\overline{C A R}}_{i}\left(T_{1}, T_{2}\right)
$$

with

$$
\operatorname{var}\left(\overline{\overline{C A R}}\left(T_{1}, T_{2}\right)\right)=\frac{1}{N^{2}} \sum_{i=1}^{N} \sigma_{i}^{2}\left(T_{1}, T_{2}\right)
$$

Given that the abnormal returns are expected to be normally distributed, it is possible to conduct a test under the null hypothesis of a zero mean. The testing procedure includes the calculation of the test statistics, and its comparison to the assumed distribution under the null hypothesis that the average abnormal return is equal to zero. The following null hypotheses are mainly tested:

$$
\Phi^{1}=\frac{\mathrm{CAR}_{\mathrm{i}}\left(\mathrm{T}_{1}, \mathrm{~T}_{2}\right)}{\sqrt{\sigma^{2}\left(\mathrm{CAR}_{\mathrm{i}}\left(\mathrm{T}_{1}, \mathrm{~T}_{2}\right)\right)}} \sim \mathrm{N}(0,1)
$$

The null hypothesis $\Phi^{1}$ tests whether the cumulative abnormal return for each security $i$ is significantly different from zero $(\mu=0)$.

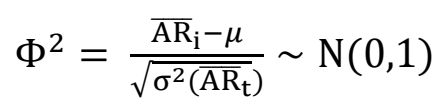

The null hypothesis $\Phi^{2}$ tests whether the average abnormal return at a specific time period $t$ is significantly different from zero.

$$
\Phi^{3}=\frac{\overline{\operatorname{CAR}}\left(\mathrm{T}_{1}, \mathrm{~T}_{2}\right)-\mu}{\sqrt{\sigma^{2}\left(\mathrm{CAR}_{\mathrm{i}}\left(\mathrm{T}_{1}, \mathrm{~T}_{2}\right)\right)}} \sim \mathrm{N}(0,1)
$$

The last null hypothesis tests for the whole matrix of cumulative abnormal returns, as to whether or not it is statistically significantly different from zero.

\section{Empirical Results}

The prevalent significance test for event study methodology is the t-test, with the assumption of uncorrelated and equally distributed residuals. The t-test can be undertaken not only to test the significance from zero, but also to test on higher values, also called power or 
objective value $\mu$. The power $\mu$ addresses the likelihood of rejecting the null-hypothesis for a specific value of abnormal return associated with the event. The economically plausible abnormal return range is driven by the descriptive analysis which indicated that the difference in total return index from after minus before sustainability report release, was around 3,5 index points. Hence, the objective values to be tested for are set from $0 \%$ to $5 \%$ in $0,5 \%$ steps.

Assuming a one-sided t-test under the null of CARs greater than the respective objective values, the results of the hypotheses $\Phi^{1}$ are shown in Exhibit 3.

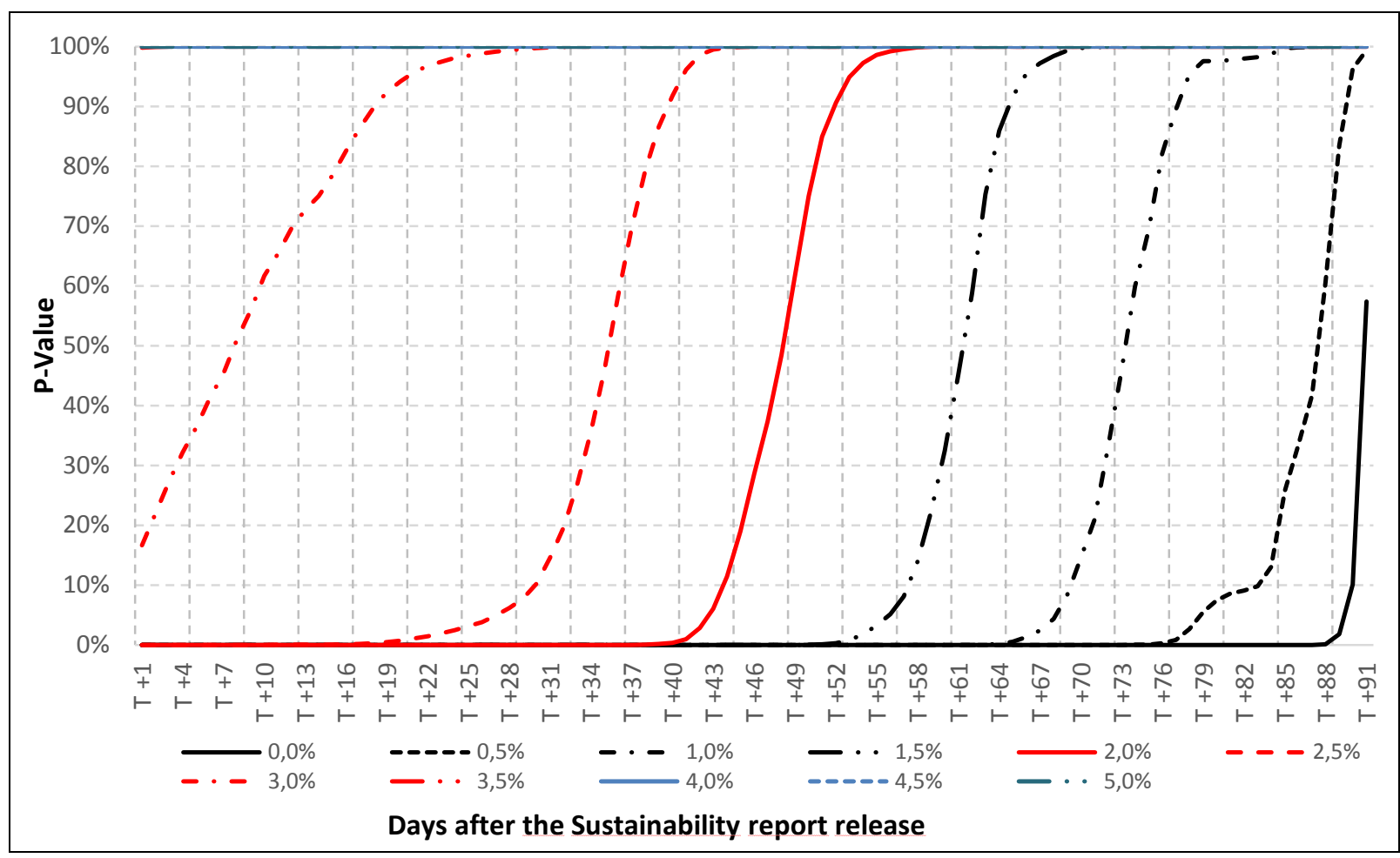

Exhibit 3: Statistical significance of CAR with a reasonable range of objective values across time

The null hypothesis to be tested is $H_{0}: C A R>0$; that is, the event of releasing sustainability reports has a impact on corporate share returns across the event window $T_{1}$ to $T_{2}$. For this, the abnormal returns of the 89 companies of the sample have been aggregated over the event window for all companies at $t+1, t+2+\ldots+t+91$ days after the sustainability report release. The ordinate indicates the p-values for rejecting the null. Hence, each line represents the p-value for the null-hypothesis, given an objective return greater than the indicated economically reasonable abnormal return range between $0 \%$ and $5 \%$ in $0,5 \%$ steps. The subsequently undertaken t-test shows that the results are significantly different from zero.

Each of the lines in Exhibit 3 shows the p-value of rejecting the hypothesis that cumulative returns are greater than the respective objective values, in relation to the days after the release of the sustainability report. Hence, for example, the hypotheses that the CAR is greater than $1.0 \%$ can be rejected after 70 days of the report release date. The hypothesis that the CAR over time is higher than $3 \%$ can already be rejected 29 days after the sustainability report release. In other words, 70 days after the release of a GRI-report, listed real estate companies exhibit a cumulative abnormal return of at least $1 \%$ and of at least $3 \%$ after almost 30 trading days.

These results can be confirmed not only over time, but also by the evidence from the ttest $\Phi^{2}$ for the cross-sectional sample. Exhibit 4 presents the results of the t-test for the statistical significance of the cumulated returns by the objective values $0 \%$ to $5 \%$, in $0.5 \%$ steps for all listed real estate companies. 


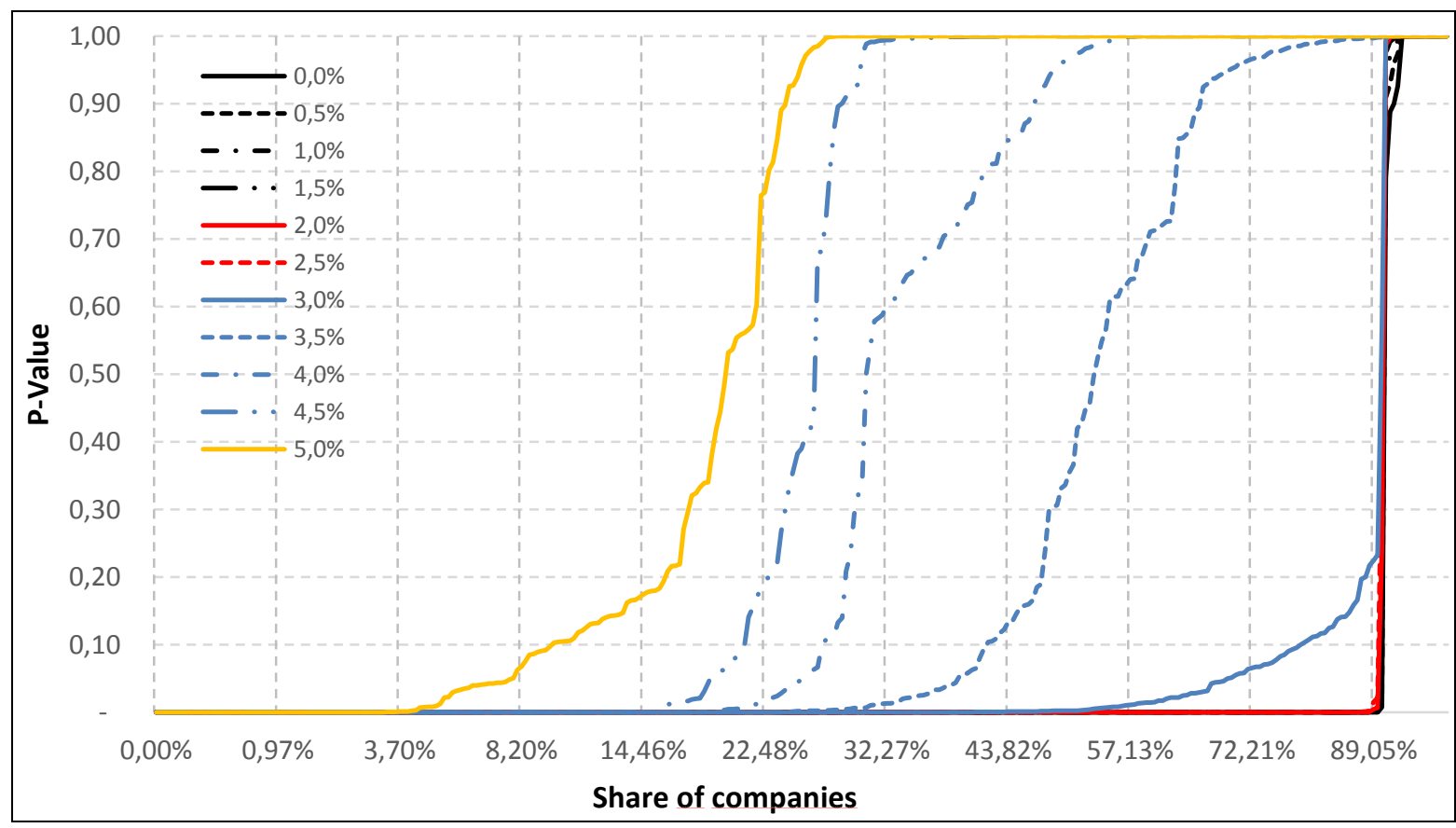

Exhibit 4: Statistical significance of cumulated abnormal returns for a range of objective values across companies

Undertaking the t-test across the 89 companies was initiated with the cross-sectional aggregation of the cumulative abnormal returns for the sample. The objective value range is $0 \%$ to $5 \%$, in $0.5 \%$ steps. The ordinate shows the p-values, and the y-axis, the share of the companies.

Each line in the exhibit shows the p-value of rejecting the hypothesis that firm's cumulative returns are greater than the respective objective values sorted by the share of companies. In other words, for almost $90 \%$ of the companies, the hypothesis that the release of a GRI-report leads to CARs below $2.5 \%$ cannot be rejected. In contrast, only $10 \%$ of the real estate firms show a statistical significant CAR above 5\%, which is not likely in in view of the results shown in the descriptive statistics. However, almost $75 \%$ of the observed firms show a significant CAR of at least 3\%. These results emphasize the importance of information on sustainability activities, as an active part of a firm's strategy with respect to both internal and external stakeholders, which result in increased growth expectations from investors and capital markets.

Finally, we present the empirical results for the entire sample, regardless of the individual heterogeneity or time-series component, i.e. the t-test for the null-hypothesis $\Phi^{3}$. Over the entire sample, the hypothesis that the release of sustainability reports has no influence on corporate value can be rejected at all conventional significance levels. More precisely, the result holds up to an objective value of CAR below $2.0 \%$ for the entire sample and confirms that the inclusion and communication of sustainability strategies has a significant impact on stock returns, based on a sample of 89 listed real estate companies and 319 events. 


\begin{tabular}{|c|c|c|}
\hline \multirow{2}{*}{$\begin{array}{c}\text { Objective } \\
\text { Value }\end{array}$} & \multicolumn{2}{|c|}{ All Sample } \\
\cline { 2 - 3 } & T-Value & P-Value \\
\hline $0,0 \%$ & 23,992 & 0,00 \\
\hline $0,5 \%$ & 20,155 & 0,00 \\
\hline $1,0 \%$ & 16,317 & 0,00 \\
\hline $1,5 \%$ & 12,480 & 0,00 \\
\hline $2,0 \%$ & 8,643 & 0,00 \\
\hline $2,5 \%$ & 4,805 & 0,17 \\
\hline $3,0 \%$ & 0,968 & 1,00 \\
\hline $3,5 \%$ & $-2,869$ & 1,00 \\
\hline
\end{tabular}

Exhibit 5: The significance of cumulative abnormal returns across time and company

t-test for the 319 observations of 89 companies over the event window of 106 days. The p-values are significant at all levels, and thus, the one-sided nullhypothesis of no impact can be rejected. The objective values or power test the significance of the indicated value of abnormal returns.

\section{Conclusion}

The inclusion of sustainability aspects into firms' core strategy is becoming more and more the rule rather than the exception, especially in the real estate industry as it accounts for a large part of the final energy consumption and greenhouse gas emissions worldwide. In this context, the efficient communication of sustainability strategies and efforts is normally provided by sustainability reports, based mainly on the international regulatory framework of the Global Reporting Initiative, GRI. In a market in which information is priced efficiently, additional information on long-term strategies should reduce asymmetries between the company and its stakeholders and lead to stronger valuation. If the release of sustainability reports provides additional information, we should expect a positive impact on corporate value. Based upon these fundamentals, the paper analyzes the impact of sustainability reports on corporate value. The descriptive and empirical analyses provide significant evidence of the value contribution of sustainability reports. Specifically, we reject the hypothesis that sustainability reports have no impact on the market value of listed real estate companies and establish a robust increase in abnormal returns of at least $2 \%$ for about $75 \%$ of the listed real estate companies. This positive effect is robust, even when considering individual and serial heterogeneity into the statistical models. Hence, the positive results provide evidence at the empirical level that sustainable reports convey information which is useful for company (e)valuation. This provides highly significant results for the market efficiency hypothesis and at the same time, that the real estate market is efficient in the sense that new information is incorporated into the share prices within a short event window.

Considering the costs of preparing sustainability reports, it is important that the results of this research confirm the payoff of such efforts. Investments in corporate sustainability can thus also be seen as an investment in corporate performance, as sustainable corporate behavior is rewarded by the market through higher stock values. Thus, the presented results could trigger further sustainability efforts in the real estate sector. 


\section{References}

Albers, C., Guenther, T. (2010) Disclose or Not Disclose: Determinants of Social Reporting for STOXX Europe 600 Firms, Zeitschrift für Planung \& Unternehmenssteuerung 21(3), pp. 323-247.

Alonso-Almeida, M. M. (2009) Use of ICTs to generate trust in shareholder and investors in companies, Argos 26(51), pp. 6-26.

Armitage, S. (1995) Event study methods and evidence on their performance, Journal of Economic Surveys 9(1), pp. 25-52.

Bauer, R., Koedijk, K., Otten, R. (2005) International evidence on ethical mutual fund performance and investment style, Journal of Banking \& Finance 29(7), pp. 1751-1767.

Ball, J., Brown, P. (1968) An Empirical Evaluation of Accounting Income Number, Journal of Accounting Research 6(2), pp. 159-178.

Brown, S. J., Warner, J. B. (1980) Measuring Security Price Performance, Journal of Financial Economics 8(3), pp. 205-258.

Brown, S. I., Weinstein, M. I. (1985) Derived factors in event studies, Journal of Financial Economics 14(3), pp. 491-495.

Brundtland Report (1987) Report of the World Commission on Environment and Development: Our Common Future, Brussels.

Cajias, M., Bienert, S. (2011) Does Sustainability pay off for European Listed Real Estate Companies? The Dynamics between Risk and Provision of Responsible Information, Journal of Sustainable Real Estate 3(1), pp. 211-231.

Cajias, M., Geiger, P., Bienert, S. (2012) Green agenda and green performance: empirical evidence for real estate companies, Journal of European Real Estate Research 3(2), pp. 135-155.

Campbell, J., Lo, A., MacKinlay, C. (1997) The Economics of Financial Markets, Princeton, NJ: Princeton University press.

COM - Commission of the European Communities (2001) Green Paper - Promoting a European Framework for Corporate Social Responsibility, COM (2001) 366 final, Brussels, pp. 1-32.

COM - Commission of the European Communities (2011) A renewed EU Strategy 2011-14 for Corporate Social Responsibility, COM (2011) 0681 final, Brussels.

Dilling, P. F. A. (2009) Sustainability reporting in a global context: What are the characteristics of corporations that provide high quality sustainability reports? - An empirical Analysis, International Business \& Economics Research Journal 9(1), pp. 19-31.

Eurosif (2014) European SRI Study 2014, Brussels.

Fama, E. F. (1970) Efficient Capital Markets: A Review of Theory and Empirical Work, The Journal of Finance 25(2), pp. 383-417.

Gamerschlag, R., Moeller, K., Verbeeten, F. (2011) Determinants of Voluntary CSR Disclosure: Empirical Evidence from Germany, Review of Managerial Science 5(2-3), pp. 233-262.

Gebken, T. (2008) The Dynamics within Merger Waves: Evidence from the Industry Merger Waves of the 1990s, Doctoral Thesis, European Business School Oestrich-Winkel.

Geczy, C., Stambaugh, R. F., Levin, D. (2005) Investing in Socially Responsible Mutual Funds, Available at SSRN 416380.

Gilbert, D. U., Rasche, A. (2007) Discourse ethics and social accountability: the ethics of SA 8000, Business Ethics Quarterly 17(2), pp. 187-216.

Global Reporting Initiative (2002) Sustainability reporting guidelines on economic, environmental and social performance, Boston: Coalition for Environmentally Responsible Economies.

Jones, S., Frost, G., Loftus, J., van der Laan, S. (2007) An empirical examination of the market returns and financial performance of entities engaged in sustainability reporting, Australian Accounting Review 17(1), pp. 78-87.

Krajnc, D., Glavi, P. (2005) A model for integrated assessment of sustainable development, Resources, Conservation and Recycling 43(2), pp. 189-208.

Laufer, W. S. (2003) Social Accountability and Corporate Greenwashing, Journal of Business Ethics 43(3), pp. 253-261.

Lee, M. D. P. (2008) A review of the theories of corporate social responsibility: its evolutionary path and the road ahead, International Journal of Management Reviews 10(1), pp. 305-328.

Davies, P, L., Canes, M. (1978) Stock prices and the publication of second-hand information, Journal of Business 51(1), pp. 43-56.

MacKinley, A. C. (1997) Event Study in Economics and Finance, Journal of Economic Literature 35(1), pp.1339. 
McWilliams, A., Siegel, D. (1997) Event studies in management research: Theoretical and empirical issues, Academy of management journal 40(3), pp. 626-657.

Melé, D., Debeljuh, P., Arruda, M. C. (2006) Corporate ethical policies in large corporations in Argentina, Brazil and Spain, Journal of Business Ethics 63(1), pp. 21-38.

Murray, A., Sinclaire, D., Power, D., Gray, R. (2006) Do financial markets care about social and environmental disclosure?, Accounting, Auditing and Accountability Journal 19(2), pp. 228-255.

Münchner Rückversicherungsgesellschaft (2013) Topics Geo: Natural catastrophes 2012 - Analyses, assessments, positions, Munich.

Nelson, A., Rakau, O., Doerrenberg, P. (2010) Green Buildings - A Niche becomes Mainstream, RREEF Research.

Peterson, P. P. (1989) Event Studies: A Review of Issues and Methodology, Quarterly Journal of Business and Economics 28(3), pp. 36-66.

Ramus, C. A., Montiel, I. (2005), When are corporate environmental policies a form of greenwashing?, Business Society 44 (4), pp. 377-414.

Sharpe, W. F. (1963) A simplified model for portfolio analysis, Management Science 9(2), pp. 277-293.

Sherman, W. R. (2011) The global reporting initiative: what value is added?, International Business \& Economics Research Journal 8(5), pp. 9-22.

Skouloudis, A., Evangelinos, K., Kourmousis, F. (2009) Development of an evaluation methodology for triple bottom line reports using international standards on reporting, Environmental Management 44(2), pp. 298-311.

Spreemann, K. (2006) Portfoliomanagement, $3^{\text {rd }}$ Edition, Munich.

Turcsanyi, J., Sisaye, S. (2013) Corporate Social Responsibility and its link to financial performance Application to Johnson \& Johnson, a pharmaceutical company, World Journal of Science, Technology and Sustainable Development 10(1), pp. 4-18.

UNEP Sustainable Buildings \& Climate Initiative (2009) Buildings and Climate Change - Summary forDecision-Makers, Paris.

Weber, M. (2008) The business case for corporate social responsibility: A company level measurement approach for CSR, European Management Journal 26(4), pp. 247-261. 